\title{
Čovjek i njegova sloboda
}

\author{
Borislav DADIĆ - CeCILIJA NEKIĆ* \\ UDK: $111^{*} 123.1^{*} 17 \cdot$ Pregledni članak \\ Primljeno: 17. siječnja 2017. • Prihvaćeno: 8. svibnja 2017.
}

${ }^{*}$ Izv. prof. dr. sc. Borislav

Dadić, Odjel za filozofiju, Obala kralja Petra Krešimira IV. br. 2, 23000 Zadar, Hrvatska, bdadic@unizd.hr

Cecilija Nekić, mag. educ. phil., mag. philol. ital., VII. gimnazija, Križanićeva 4, 10000

Zagreb, Hrvatska, cecilija.nekic@gmail.

Sažetak: U radu obrađujemo slobodu kao čovjekovu osobitu savršenost. Polazimo od metafizičke konstitucije osobe kako bismo jasno prikazali zašto je čovjek slobodno biće. Riječ je o čovjeku kao supstancijalnom jedinstvu forme i materije te o razumu i volji, dvjema moćima svojstvenima isključivo čovje$k u$. Donosimo odredene filozofske refleksije o ljudskoj slobodi $i$ kritičku prosudbu aktualnih društvenih pojava poput rodne ideologije i pobačaja, kao eklatantne primjere neprihvatljivoga shvaćanja ljudske slobode. Zbog mnogih problema vezanih za suvremeno shvaćanje čovjeka želimo skrenuti pozornost na neotudivu vrijednost osobe te najviši čin u kojem se sloboda očituje. Riječ je o sposobnosti osobe za samoostvarenje u autentičnoj ljubavi.

Ključne riječi: metafizička konstitucija, sloboda, osoba, rodna ideologija, pobačaj, samoostvarenje, ljubav.

\section{Uvod}

Naše je vrijeme obilježeno borbom za očuvanje ljudske osobe, njezina dostojanstva i integriteta. Ideja za ovaj članak nastala je u promatranju zbilje. U vrtlogu opće zbunjenosti i neinformiranosti pokušavaju se nametnuti ideje protivne ljudskoj naravi. A najučinkovitiji način da se postignu ciljevi koji opravdavaju sredstva jest onaj koji proklamira slobodu. Stoga je svrha ovoga članka pokazati tko je uistinu čovjek, što je to njemu intrinzično, kamo je usmjeren i koja je njegova zadaća kao najsavršenijega bića na Zemlji. Aristotelovsko-tomistički nauk o čovjeku smatramo najkonzistentnijim pa se filozofskim principima i nazivljem koristimo po uzoru na ta dva velikana klasične filozofije. Najprije analiziramo metafizičku konstituciju osobe. Čovjek je naime biće koje je po svojoj duši smješteno u 
carstvu stvorenja na međi dvaju svjetova, materijalnoga i duhovnoga. ${ }^{1}$ No analiza metafizičke konstitucije čovjeka ne će se svoditi samo na tvrdnju o čovjekovoj neobičnosti, nego će uključivati istraživanje konstitutivnih principa čovjeka, kao i osobitih moći djelovanja toga bića. Budući da se čovjek od ostalih živih prirodnih bića izdvaja po dvjema posebnim moćima djelovanja, a to su razum i volja kao najviše moći duše ${ }^{2}$, njima ćemo posvetiti više pozornosti, naravno, u okvirima mogućega prostora ovoga članka. Posebnu pozornost posvetit ćemo analizi tih moći s gledišta slobode kao glavne karakteristike osobe. Snagom razuma čovjek misli, vrjednuje i prosuđuje stvarnost oko sebe. Osoba snagom svoje slobodne volje (libero arbitrio) bira ono što joj razum predlaže te tako ostvaruje svoju slobodu ili pak odbacuje predloženo dobro i okreće se nekom parcijalnom dobru te se upućuje na putove neslobode. Sloboda je shvaćena kao ljudska savršenost i sve je naše slobodno djelovanje usmjereno na biranje dobra kao dobra. Spominjemo i aktualne probleme koji nastaju upravo zbog krivoga poimanja slobode i ljudske osobe. U završnom dijelu usmjereni smo na govor o ljudskoj osobi. Objašnjavamo tko je uistinu osoba i koji je vrhovni čin očitovanja slobode.

\section{Metafizička konstitucija osobe}

Svakom se od nas jednom nametne pitanje tko je to čovjek. Možemo li uopće razviti objektivan govor o sebi samima? Mnoge discipline proučavaju čovjeka, no uvijek naglašavajući onaj aspekt za koji su specijalizirane. S druge strane, filozofska antropologija obuhvaća sve ljudske aspekte koristeći se istraživanjima drugih znanosti te ih objedinjuje filozofskim znanjem radi davanja cjelovite slike o čovjeku. Pozitivne znanosti koje se bave proučavanjem čovjeka pod vidom njegove tjelesnosti ostvarile su golemi razvoj i omogućile nam mnogo dublju spoznaju o ljudskom organizmu, nego što su je imali na raspolaganju filozofi u proteklim razdobljima. Sva ta znanja pomažu nam u filozofskoj refleksiji o čovjeku promatranom u njegovoj sveukupnosti. Zato ćemo i mi ovo izlaganje započeti filozofskom refleksijom o tjelesnoj komponenti ljudskoga bića.

\subsection{TIJELO KAO MATERIJALNI PRINCIP}

Iskustvo nam govori da prvo primjećujemo konkretno tijelo čovjeka. Svatko od nas po tijelu dolazi u doticaj s okruženjem u kojem živi te ga ono čini bićem koje zauzima prostor. Ljudsko tijelo kao biološki organizam određeno je osobitim ka-

\footnotetext{
${ }^{1}$ Usp. TOMA AKVINSKI, S. Th., I., q. 77, a 2.

${ }^{2}$ Usp. TOMA AKVINSKI, S. Th., I. q. 77; vidi također De anima, a. 13, ad. 10. Toma te moći duše naziva razumskim moćima i posebno ih obrađuje u pitanjima koja slijede. Moć razuma posebno obrađuje u pitanju 79, a moć volje u pitanju 82 istoga dijela Summe.
} 
rakteristikama zajedničkim svim predstavnicima ljudskoga roda i pod tim ga vidom proučavaju pozitivne znanosti. Nadalje, iz osobnoga iskustva znamo da je, ipak, svako ljudsko tijelo po nečem jedinstveno, da u istim životnim okolnostima može reagirati različito. Iz te vrlo jasne činjenice zaključujemo da tijelo određuje pojedinca, on je prepoznat kao individua jer ima konkretno tijelo. ${ }^{3}$

$S$ druge strane, budući da je moje tijelo samo moje, nitko drugi ne može imati neposredan uvid u to kako se u njemu osjećam, kako ga doživljavam. Zato je vrlo važno pri filozofskoj refleksiji o ljudskoj osobi imati na umu razliku između čovjekova tijela i tjelesnosti. Ta se razlika u nekim jezicima jasno pokazuje, na primjer u njemačkom jeziku kada se tijelo promatra u njegovoj biološkoj strukturi, rekli bismo kao fizičko tijelo, naziva se Körper, a kada tijelo percipira osoba o čijem je tijelu riječ, odnosno njezin subjektivni doživljaj vlastitoga tijela naziva se Leib. ${ }^{4} \mathrm{Ti}$ jelo je naime pojam koji označava osjetilno percipiranu čovjekovu vanjštinu, kao što su percipirani i drugi objekti u prirodi, dok je tjelesnost usmjerena na čovjekovu unutrašnjost, ujedinjuje sve tjelesne osjetilnosti i čini ih osjetilnostima ljudskoga tijela. ${ }^{5}$ Zato mogu sumnjati u svoje tijelo, no ne mogu sumnjati u svoju tjelesnost.

Potrebno je napomenuti da će pojam osobe u sebi uključivati sve čovjekovo, i tijelo i tjelesnost. Toga je svjesna E. Stein kada piše da je »fenomen jednog psihofizičkog individue definitivno različit od onog jednog fizičkog tijela (physischer Körper), kao i od vlastitog tijela (Leib) obogaćenog osjetilnošću, kao tijela kojem pripada jedno Ja sposobno imati senzacije, misli, osjećanje i htijenje $\ll^{6}$.

\subsection{DUŠA KAO DUHOVNI ČOVJEKOV PRINCIP}

Vanjske osobine čovjeka, kao i njegovi čini, upućuju nas na nešto duboko unutrašnje, na njihov metafizički temelj. Riječ je o duhovnom principu koji tradicionalno zovemo duša. Rečeno jednostavnim rječnikom, tijelo je materija, a duša oblikuje tu materiju. »Duša je ta koja tijelo čini tjelesnim. Ona čovjeku daje njegova ljudska određenja, kao što su tjelesnost, oformljujući prvu materiju, ali i njegove bitne

\footnotetext{
${ }^{3}$ Usp. R. LUCAS LUCAS, L'uomo lo spirito incarnato, Roma, 1993., 200.

${ }^{4}$ Tu razliku između Körper i Leib u njemačkom govornom prostoru izvrsno su obradili E. HUSSERL (usp. Meditazioni cartesiane, Milano, 2002., 119.-121.; Idee per una fenomenologia pura e per una filosofia fenomenologica, Torino, 1981. - 1982.) i M. SCHELER (usp. Il formalismo nell'etica e l'etica materiale dei valori, Cinisello Balsamo, 1996., 477.523.). Za tu nam problematiku mogu biti korisne i sljedeće dvije knjige: V. MELCHIORE, Corpo e persona, Genova, 1991.; P. MICCOLI, Il corpo dicibile. L'uomo tra esperienza e significato, Roma, 2003.

${ }^{5}$ Usp. isto, 197.

${ }^{6}$ E. STEIN, Il problema dell'empatia, Roma, 1998., 70.
} 
moći djelovanja: umske, osjetilne i vegetativne. $\ll^{7}$ Lakše je prihvatiti ono što vidimo, zato ljudsko tijelo nije točka prijepora. No je li to razlog da ne idemo dalje od pojavnosti i na temelju zaključivanja dođemo do stvarnosti koje nisu podložne perceptivnoj spoznaji? Prihvaćamo li da postoji ultraljubičasto zračenje ili pak gravitacijska sila, iako ih ne vidimo? Tijelo nikad ne bi bilo ni živo ni ljudsko da nije ujedinjeno s ljudskom dušom. S druge strane, duša je duhovna stvarnost te joj je kao takvoj potreban kompatibilan princip da bi mogla egzistirati i u potpunosti djelovati u materijalnom svijetu. Taj formalni princip jamči jedinstvenost $\mathrm{i}$ pojedinačnost unatoč bilo kojoj promjeni koju čovjek prolazi tijekom svoga života. Nadalje, ljudska je forma i subzistentna. To znači da posjeduje vlastiti akt bivstvovanja (actus essendi) ${ }^{8}$ čijom snagom može bivstvovati neovisno od tijelu. Duša taj akt bivstvovanja donosi tijelu čineći s njime supstancijalno jedinstvo. Dokaz za njezino samostalno bivstvovanje jesu djelatnosti koje obavlja neovisno o tijelu. Duša je duhovno počelo života čovjeka i ona oblikuje materiju u živo ljudsko tijelo. Zato ona čovjeku donosi bit po kojoj je čovjek pripadnik ljudske vrste. Ali kako je duša istovremeno i neovisna u bivstvovanju od tijela, mora imati svoj metafizički princip koji joj osigurava neovisnost. To je njezin akt bivstvovanja koji ona donosi čovjeku. On je poseban za svaku pojedinu ljudsku osobu i ne može ga se darovati nekomu drugomu niti ga se može otuđiti. Osoba doista ima svoj bitak u sebi i za sebe, ali ne i od sebe jer nije sama sebe stvorila. ${ }^{9}$ Taj akt bivstvovanja dobila je u činu stvaranja od prvoga počela koje T. Akvinski metafizički definira kao Ipsum Esse Subsistens, a E. Gilson smatra da je taj nauk »kamen zaglavni « njegove metafizike koju on originalno naziva $\gg$ metafizika Izlaska $\ll .{ }^{10}$ Zato, po našem mišljenju, jedino plauzibilno i konzistentno rješenje upućuje na stvaranje ex nihilo jer objašnjava podrijetlo samoga akta bivstvovanja kao najdubljega i posljednjega temelja svake osobe, a time i njezine neponovljivosti. Navedeni metafizički pojam za bitak dugujemo T. Akvinskom koji ga naziva actus essendi, a koji smo najspretnije preveli na hrvatski kao 'akt bivstvovanja'. Tako svaka ljudska osoba roditeljima duguje tijelo, a dušu duguje onomu koji mu je darovao akt bivstvovanja.

\footnotetext{
${ }^{7}$ B. DADIĆ, Filozofija i zbilja, Split, 2010., 210.

${ }^{8}$ Usp. TOMA AKVINSKI, De Pot., q.3, a. 9, c. Usporedi također R. PIETROSANTI, L'anima umana nei testi di S. Tommaso. Partecipazione - spiritualità - immortalità, Bologna, 1996., 143.

${ }^{9}$ Usp. C. CARDONA, Matafisica del bene e del male, Milano, 1991., 62.-63.

${ }^{10}$ Izvrsno tumačenje te originalne metafizike Tome Akvinskoga imamo u Gilsonovim djelima, a posebno u Uvodu u kršćansku filozofiju (hrv. izd.: Zagreb, 1995.) i Bitak i bit (hrv. izd.: Zagreb, 2010.). Posebno upućujemo na osmo poglavlje knjige Uvod u kršćansku filozofiju, u kojem je objašnjena participacija čina bivstvovanja pojedine osobe na Ipsum Esse Subsistens.
} 


\subsection{JEDINSTVO MATERIJALNOGA I DUHOVNOGA PRINCIPA U ČOVJEKU}

Čovjek, metafizički promatran, predstavlja supstancijalno jedinstvo temeljnih metafizičkih principa, duše i tijela, koji se, prema Aristotelu, odnose kao akt i potencija. ${ }^{11}$ Ti metafizički principi sami za sebe za pojedinog čovjeka ne znače ništa, no zbog supstancijalnoga jedinstva duše i tijela čovjek može reći ja, može osjećati i misliti kao konkretna osoba. Aristotelovskim terminima rečeno, čovjek je supstancijalno jedinstvo forme i materije. Duša je dakle duhovni princip po kojem materija postaje ljudsko tijelo. Samo zahvaljujući metafizičkom jedinstvu i suradnji tih dvaju kompatibilnih principa, postoji supstancija koju nazivamo čovjek. I to ne neki univerzalan, pojmovan čovjek, nego svaki od nas, točno određena konkretna, realna ljudska osoba. Na to čovjekovo metafizičko jedinstvo upućuje nas iskustvo našega života. Naime, nakon biološke smrti ljudskoga organizma prestaju sve njegove vitalne funkcije i postupno nastupa raspadanje tijela, što upućuje na zaključak da duša više nije nazočna u njemu. Iako različita i naizgled dva nespojiva principa, za vrijeme čovjekova života uvjet su jedno drugomu, neprestano se nadopunjavaju. Čovjek je po tijelu podložan promjenama, ranjiv i kontigentan, dok mu duša daje stalnost $\mathrm{i}$ konzistentnost u tim mijenama te tako štiti i jamči jedinstven i neotuđiv identitet osobe. Isto tako, po duši je čovjek svjestan svog toga stanja. On jedini zna da mora biološki umrijeti. Ljudsko bivstvovanje nije samo kvantitativni skok, pa se ljudska vrsta ne može smatrati samo evolucijski naprednijom među ostalim živućim organizmima. U protivnom se čovjek ne bi mogao sporiti s drugima o tome tko on uopće jest. Zato je potrebno reći nešto o ljudskim moćima, koje čovjeku pripadaju po njegovoj naravi te su neotuđive kao takve.

\section{Posebne ljudske moći}

Suglasni smo s onim filozofima koji smatraju da čovjek nije čista eksteriornost, samo neki fenomen koji opažaju naša osjetila, nego da on posjeduje i nutrinu koja se često jasno odražava na vanjštini. Prema Tomi Akvinskom čovjek treba biti shvaćen kao horizont stvaranja, točka dodira između materijalne i duhovne stvarnosti. ${ }^{12}$ Kada govorimo o duhovnom aspektu čovjeka, tada se češće koristimo pojmom ljudska osoba. Tim pojmom ne želimo označiti samo individuu ni samo jedno prirodno živo biće koje pripada najsavršenijoj biološkoj vrsti na Zemlji. Naprotiv, njime želimo izraziti cjelokupnu čovjekovu stvarnost, njegovu materijalnu i duhovnu dimenziju.

Čovjekova duhovna dimenzija očituje se u njegovoj duši koja se pak očituje svojim djelovanjem snagom moći koju posjeduje. Među moćima djelovanja koje posjedu-

\footnotetext{
${ }^{11}$ Usp. ARISTOTEL, O duši, II., 412a - 412b.

${ }^{12}$ Usp. TOMA AKVINSKI, CG., II, c. 68; IV, c. 55.
} 
je ljudska duša posebno se ističu dvije: razum i volja. Zato ćemo sada njima posvetiti malo pozornosti.

\subsection{RAZUM I SAMOSVIJEST}

Svi dobro razumijemo kada netko postupa razumno, a kada ne. Ipak, danas se često u javnim medijima, pa i u stručnoj literaturi, događa zbrka oko pojmova razum, um, mozak, inteligencija i sl. Stoga nam se čini korisnim, na tragu Tome Akvinskoga, pojasniti u kojem se smislu mi koristimo pojmom razuma. O razumu znamo iz njegova djelovanja, a dva su načina djelovanja ljudskoga razuma. U širem ga smislu (ratio) shvaćamo kao sposobnost spoznavanja istine, a u užem smislu kao sposobnost stvaranja pojmova, donošenja sudova i zaključaka. Kada razum shvaća neposredno stvarnost, tada govorimo o umu (intellectus) te se u tom slučaju odnosi na intuitivno spoznavanje istina. No valja napomenuti da ratio i intellectus nisu dvije različite moći duše, nego dva vida djelovanja iste moći. ${ }^{13}$ Po toj moći ljudsko biće posjeduje materijalne stvarnosti na nematerijalan način. To je temeljna radnja razuma: donošenje pojmova. Priroda pojma ukazuje na način čovjekova bivstvovanja. Itekako je relevantna činjenica da on može posjedovati stvari kao mišljene. Budući da živi u svijetu koji se neprestano mijenja te je kao takav kontingentan, razum je moć koja nas na neki način čuva od propadljivosti. Budući da čovjek nije svjestan samo svijeta koji ga okružuje nego i sebe samoga, nužno je navesti samosvijest kao vlastitost ljudskoga razuma. Zahvaljujući razumskoj spoznaji, otvara se i promišlja o svojoj unutrašnjosti, u njoj sazrijeva svijest o vlastitom ja. ${ }^{14}$ Ta vlastitost ljudskoga razuma otvara nam neprocjenjivu mogućnost gospodarenja nad vlastitim ja: svjesnost o sebi nije bespotrebna stvarnost, nego me upućuje na pogled u moju unutrašnjost, na afekte koji me pokreću, na misli koje su dio mene. Um se na neki način vraća sebi. Biti samosvjestan znači posjedovati samog sebe na određen način, podudarati se sa samim sobom te ne biti razasut kao što je razasuto sve ono što je protežno. ${ }^{15}$ Nezaobilazan je i nadasve zanimljiv trenutak samosvijesti kada ona dopušta subjektu percipirati stvarnosti slične njemu, koje se po njihovu načinu ponašanja otkrivaju kao one kojima pripada isto dostojanstvo. Čovjek dakle može biti svjestan toga kakav je uistinu. Ipak, čovjek ponekad savršeno zna što bi trebao činiti, no ipak miruje. Sam razum nije dovoljan za objašnjenje čovjekova djelovanja. Usko uz njega vezana je volja, koja ima ulogu odlučivanja.

\footnotetext{
${ }^{13}$ Usp. TOMA AKVINSKI, S. Th., I, q. 79, a. 8; De Ver., q. 15, a. 1.

${ }^{14}$ Usp. A. ALESSI, Sui sentieri dell'uomo, Roma, 2006., 155.

${ }^{15}$ Usp. S. VANNI ROVIGHI, Elementi della filosofia, III, Brescia, 1995., 176.
} 


\subsection{Volja}

Razumom čovjek spoznaje stvarnost te percipira dobro i vrijednosti, no razumom ih ne može posjedovati. Tu nastupa druga ljudska moć koja pretpostavlja razumsko djelovanje: volja. Treba odmah dati definiciju volje: to je duhovna težnja prema spoznatom dobru. Čovjek ima uz prirodni impuls težnju koja taj impuls nadilazi. To je razumska težnja. Isto kao što je i prirodni impuls težnja za usavršavanjem bića, dakle za postizanjem dobra, tako je i razumska težnja, tj. volja, težnja za postizanjem dobra koje joj razum predlaže. Volja dakle teži onom za što već prethodno zna da je dobro. Za razliku od razuma, volja teži spoznatom objektu, ne radi pokazivanja istoga, nego da ga obgrli. ${ }^{16}$ Ta moć pretpostavlja slobodu. Nikad ne bismo mogli ni o čemu odlučiti da nismo slobodna bića. Bez slobode ljudske bi moći bile besmislene i njihovo bi postojanje u jednu ruku bilo kontradiktorno. Kao što i svaki mehanizam dolazi bez viška dijelova, tako i ljudsko biće ne posjeduje ništa bespotrebno. Volja nas čuva od čistoga putenoga stanja, otvara nam vrata nadosjetilnoga, daje nam mogućnost odgoja naših strasti i čuva nas pogubnosti nižih strasti i života nedostojnoga čovjeka. No volja ne može djelovati drukčije nego u slobodi. Zato je prijeko potrebno objasniti taj aspekt ljudske naravi. Pojmom sloboda otvaraju se vrata ljudskoj osobi za predaju vrijednostima i otvaranje ljubavi.

Treba reći da su sve, pa i te najviše moći duše kod čovjeka u potenciji. Dakako, riječ je o aktivnoj potenciji ili potenciji djelovanja koju treba razlikovati od pasivne potencije ili potencije bivstvovanja. ${ }^{17}$ Te moći duše treba proučavati u njihovu djelovanju kako bismo upotpunili našu spoznaju o ljudskoj osobi. Pri našem istraživanju vodit ćemo se klasičnim filozofskim aksiomom: agere sequitur esse.

\section{Sloboda kao čovjekova osobita savršenost}

\section{1. Čovjekovo DJELovanje}

Čovjek, kao i ostala realna bića, osim što bivstvuje, može i raznoliko djelovati. Tako može hodati, jesti, trčati, padati, graditi, spavati, spoznavati, odlučivati i sl. Među tim mnogim djelovanjima, koje čovjek obavlja, samo su neka čovjekova djelovanja u pravom smislu riječi, tj. ona koja on obavlja kao čovjek. Zato je klasična filozofska misao razlikovala čovjekova djela (actus humanus) od djela čovjeka (actus hominis). Prema Tomi Akvinskom čovjek se razlikuje od drugih neracionalnih bića upravo po tome što je on gospodar svojih čina. A on je gospodar svojih čina po razumu i volji. Zato su u pravom smislu riječi čovjekovo djelovanje, a nas ovdje zanima upra-

\footnotetext{
${ }^{16}$ Usp. R. LUCAS LUCAS, L'uomo lo spirito incarnato, 157.

${ }^{17}$ Usp. L. CLAVELL, M. PÉREZ DE LABORDA, Metafisica, Roma, 2006., 147.-150.
} 
vo to, oni $\gg$ čini koji proizlaze iz slobodne volje $\ll{ }^{18}$. Druga djela koja čovjek može obaviti, a koja ga ne razlikuju od ostalih neracionalnih bića, poput probave hrane, nesvjesna pokreta rukom ili rada srca jesu njegova djela, ali ne ako je čovjek i zato se nazivaju djela čovjeka (actus hominis). ${ }^{19}$

Čovjek djeluje snagom svoje racionalne naravi i to je djelovanje vrlo jasno usmjereno jer uvijek postiže neki rezultat. Isto tako, ne može htjeti neki predmet, a da ne spozna njegovu vrijednost. Drugim riječima, pokretači čovjekova djelovanja jesu motivi koji su zapravo percipirano i prosuđeno dobro. ${ }^{20} \mathrm{Na}$ isti je način dobro sadržano i u svrsi čovjekova djelovanja, u ciljevima koje teži postići. Čovjek teži nekom cilju jer je u njemu sadržana određena vrijednost. To znači da nas vrijednosti potiču na djelovanje te njima i težimo po naravi. Vrijednosti su dakle sadržane u stvarnosti, no nužno je da ih netko prepozna kao vrijednosti, zato kažemo da su utemeljene na odnosu između čovjeka i stvari. ${ }^{21}$ Iz dosad izloženoga zaključujemo da se čovjek pita, nemiran je zbog urođene težnje za nečim što još ne posjeduje. A upravo vrijednost izriče ono što čovjeku nedostaje. Možemo dakle naći definiciju dobra s pomoću usavršavanja. ${ }^{22}$ No ljudsko djelovanje ima usavršavajuću ulogu samo ako je slobodno. A kada je riječ o slobodi, više ne govorimo o težnji prema spoznatom dobru, nego o ostvarenju toga dobra: čovjek ili će djelovati ili ne će. ${ }^{23}$ Vidimo koliko je važna sloboda za ljudsku egzistenciju. Zato je potrebno reći nešto više o toj vlastitosti ljudske osobe.

\subsection{Filozofsko RazumijeVAnje Slobode}

Najaktualnije su rasprave one koje se tiču slobode shvaćene u širem društvenom smislu kao neograničavanje čovjeka u djelovanju. Riječ je o socijalnoj i političkoj slobodi kao temeljnim ljudskim pravima i obvezama, koja se često naziva sloboda od i o njoj će biti još riječi. Ta je sloboda zajamčena Općom deklaracijom o ljudskim

\footnotetext{
${ }^{18}$ Usp. TOMA AKVINSKI, S. Th., I-II, q. 1, a. 1, c: »Illae ergo actiones prorie humanae dicitur, quae ex voluntate deliberata procedunt.« Naime, već je Aristotel smatrao da čovjek djeluje kao čovjek kada izvršava voljno djelovanje, a to je ono djelovanje koje se počelo nalaziti u onome koji djeluje, spoznajući pojedinačne okolnosti u kojima se realizira samo djelovanje (usp. ARISTOTEL, Nikomahova etika, III).

${ }^{19}$ Treba napomenuti da se u naše vrijeme takvi čini često i ne nazivaju djelima (usp. J. de FINANCE, Etica generale, Cassano Murge, 1989., 31.).

${ }^{20}$ Usp. J. de FINANCE, Saggio sull'agire umano, Città del Vaticano,1992., 40. Dakle, nužno je da objekt htjenja bude spoznat jer, kako kaže R. McInerny: »Ne možemo htjeti ono što ne znamo.« (R. MCINERNY, Aquinas on Human Action. A Theory of Practice, Washington, 2012., 53.)

${ }^{21}$ Usp. J. M. BOCHENSKI, Uvod u filozofsko mišljenje, Split, 1997., 77.

${ }^{22}$ Usp. J. de FINANCE, Saggio sull'agire umano, 137.

${ }^{23}$ Usp. isto, 189.
} 
pravima, na kojoj se trebaju temeljiti državni zakoni. Ipak, sloboda shvaćena u jednom dubljem, psihološkom smislu jest ona koju bismo htjeli postaviti u središte ovoga rada. Ona je status ljudskoga bića koje bilo da čini dobro ili zlo, čini ga nakon što je promislilo; zna što hoće i zašto to hoće. U psihološkom smislu slobodu poimamo kao imanentan čin volje. ${ }^{24}$ Zato se volji pridjeva atribut slobodna. Ako je sloboda oznaka voljnoga čina, čovjekovo je djelovanje slobodno. Riječ je o slobodi volje, znanoj kao libero arbitrio, dobro znanom latinskomu izrazu koji je skovao još Aurelije Augustin. Budući da podrazumijeva i promišljanje, libero arbitrio neodjeljivo je povezan s razumom. Štoviše, razum je korijen slobode volje. Svojom voljom ne mogu htjeti nešto što još ne poznajem. Moram poznavati to što želim, a želim jer je to dobro, a ne jer sam ga spoznala. ${ }^{25}$ Sama spoznaja nekoga predmeta ne potiče volju na htijenje; potiče je spoznato dobro u predmetu.

Ovdje se postavlja pitanje u kakvoj je vezi spoznaja s voljom kada je poznato da je spoznaja djelatnost razuma, a težnja (appetitus) je djelatnost volje. A s druge strane, volja i razum različite su moći duše. ${ }^{26}$ No zanimljivo je da Toma obje moći svrstava u razumske moći. On to čini jer volju definira kao razumsku težnju prema dobru da bi je razlikovao od osjetilne težnje (appetitus sensitivi). Osjetilna težnja usmjerena je na neko pojedinačno dobro, hic et nuc; dok je volja, kao razumska težnja (appetitus intellectivi), usmjerena prema univerzalnom dobru. Prema Tomi univerzalno dobro može doseći samo razum i ono je vlastiti objekt volje. ${ }^{27}$ Zato volja u svom djelovanju mora surađivati s razumom. No ovdje se pojavljuje dvojba tko zapravo odlučuje pri izboru dobra: razum, odnosno objekt koji razum spoznaje, ili volja? Tu dvojbu S. Vanni Rovighi sintetizirala je sljedećim riječima: »ili izbor nije determiniran od suda - tada je slijep - ili je determiniran od suda - tada dolazi od objekta, ne od mene, dakle nije slobodan. ${ }^{28}$ Prvo što treba reći jest da taj sud koji donosi razum nije potpuno teoretski, nego je praktični sud kojem slijedi izbor, a Toma ga naziva iudicium electionis ${ }^{29} \mathrm{i}$ on je donesen na poticaj volje. Zato, ako se pitamo što je onda korijen ljudske slobode, složit ćemo se sa S. Vanni Rovighi koja kaže da ovisi o točki promatranja. Ako se pak pod korijenom misli na subjekt slobode, onda je to

\footnotetext{
${ }^{24}$ Usp. J. de FINANCE, Esistenza e libertà, Città del Vaticano, 1990., 11.

${ }^{25}$ Usp. J. de FINANCE, Saggio sull'agire umano, 106.

${ }^{26}$ Usp. TOMA AKVINSKI, S. Th., I, q. 80, a. 1. Toma se ovdje poziva na Aristotela (De Anima, II.) i na Ivana Damaščanskog (De fide orth., 2, 22).

${ }^{27}$ Usp. TOMA AKVINSKI, S. Th., II-II, q. 25, a. 2: »Quia enim voluntatis obiectum est bonum universale. $\ll$

${ }^{28}$ S. VANNI ROVIGHI, Uomo e natura, Milano, 1980., 223.

${ }^{29}$ Usp. TOMA AKVINSKI, II. Sent., d 24, q. 1, a. 3, ad 5.
} 
sigurno volja jer čovjek je slobodan u djelovanju volje; ako se pod korijenom misli na uzrok, tada je korijen izvor slobode u razumu. ${ }^{30}$

U konačnici treba reći da u mom stvarnom životu gore navedeni praktični sud utječe na moj izbor, ali on nije determinirajući. Naime, on nikada ne može pri mom izboru predložiti neko dobro koje će me nužno determinirati jer nijedan predloženi objekt ne će nikada sadržavati u potpunosti dobro kao dobro. Zato je nužna moja uloga u tom odlučivanju. Ja sam taj koji ponuđenim objektima dajem određenu težinu, dajem motiv volji koji će biti odlučujući, dakle ja sam taj koji je mene determinirao da nešto hoću ili ne ću. ${ }^{31}$ Time smo došli do veoma važnoga shvaćanja slobode koju neki nazivaju slobodom samoodređenja. Tako naš poznati dominikanac piše: $\gg$ Sloboda samoodređenja i samoodlučivanja pozitivna je vrednota, realna sposobnost čovječje osobnosti. To je moć uspoređivanja i odabiranja... U njoj sam JA, sav Ja. $\ll^{32} \mathrm{Na}$ isti način promišljao je i Toma Akvinski koji, premda je svjestan da čovjek pri izboru ima nagnuće prema objektu koji ga privlači, smatra da čovjek zahvaljujući racionalnoj naravi ima moć i nad tim nagnućem i nije nužno da će ga slijediti jer i samo nagnuće nije determinirano od drugoga, nego od samoga čovjeka. ${ }^{33}$ To u praktičnom životu znači da čovjek koji posjeduje razum i koji sam sebi određuje vlastite ciljeve treba samoga sebe uskladiti s ciljevima koje nužno zahtijeva ljudska narav. ${ }^{34}$

Od općenitoga shvaćanja došli smo do slobode kao bitnoga izraza ljudske volje. Čovjek dakle najprije promišlja pa tek onda djeluje; a sloboda koja mu to dopušta jest libero arbitrio. ${ }^{35}$ Biti slobodan znači imati mogućnost biranja među različitim mogućnostima, na primjer između ljenčarenja i ispunjavanja obveza. Znači i mogućnost odabira obveza ili pak načina ljenčarenja. Dok druga živa bića teže po nužnosti jer su determinirana svojom naravi, čovjek teži po slobodnom odabiru. On naime može izabrati ovo ili ono, učiniti ili propustiti nešto. Libero arbitrio možemo promatrati pod trima vidovima: kao libertas exercitii, tj. odlučiti djelovati ili ne; kao libertas specificationis, tj. odlučiti učiniti ovo ili ono; kao libertas contrarietatis, tj. činiti dobro ili zlo. ${ }^{36}$ Slobodu volje možemo još nazvati sloboda $z a$. Biti slobodan ne znači samo nesputanost, neovisnost. Sloboda nije samo konstitutivna činjenica ljudske

\footnotetext{
${ }^{30}$ Usp. S. VANNI ROVIGHI, Uomo e natura, 229.-231. Sada se shvaća u kojem smislu je autorica mogla prije reći: »u konačnici 'korijen' slobode je razum, odnosno sposobnost spoznaje po univerzalnim pojmovima.« (Isto, 193.)

${ }^{31}$ Usp. S. VANNI ROVIGHI, Uomo e natura, 231.

32 J. KUNIČIĆ, Pojam kršćanske slobode, u: Crkva u svijetu 3(1968.)4, 50.

${ }^{33}$ TOMA AKVINSKI, De Verit., q. 22, a. 4, c.

${ }^{34}$ Usp. J. MARITAIN, L'uomo e lo Stato, Milano, 1992., 99.

${ }^{35}$ Usp. A. ALESSI, Sui sentieri dell'uomo, 168.-169.

${ }^{36}$ Usp. B. MONDIN, L'uomo libero, Roma, 1989., 201.
} 
osobe nego je i zadaća. ${ }^{37} \mathrm{U}$ prvom redu to znači posjedovanje sebe, odnosno svijest o vlastitoj osobi, o svojim prednostima i nedostatcima. Posjedovanje sebe znači biti slobodan iznutra od afekata i strasti; znači promišljeno djelovanje, a ne slijepo reagiranje. To ne znači da osoba treba težiti ravnodušnosti, nego treba promišljati o vlastitim postupcima i stanjima. To je put samoostvarenja. Drugim riječima, sloboda za jest sloboda koja omogućava promjene. Možemo mijenjati stvarnosti, ali i sebe. Čnjenica je da se altruisti ne rađaju, a ipak postoje. Nužno je da čovjek, umjesto da je determiniran vlastitom prirodom, bude sam autor vlastite determiniranosti. ${ }^{38}$ Čovjek se može i mora mijenjati, uvijek u vidu dobra. To je dug i težak put koji zahtijeva trud i bol. I nikad ne prestaje. No to je put ljudskoga života. Nije riječ o prisili, nego o dužnosti. Od toga pozitivnoga vida slobode razlikujemo negativni, tzv. sloboda od. Ona znači odsustvo uvjetovanja, ograničenja, prisile koja bi priječila slobodno djelovanje. ${ }^{39}$ Čovjekova egzistencija nije svedena na pusti linearni tijek postojanja. Čovjek po svom bitku bivstvuje. To je bivstvovanje ujedno nužan uvjet za njegovo djelovanje. Vidimo da svatko od nas ima druge ciljeve, težnje i domete. Svatko od nas odabire put do uspjeha, do cilja za koji pronalazi sklonosti u dubini svoga bića. Sama naša težnja prema dobru koje smo spoznali razumom potvrđuje našu slobodu. Postojanje težnje racionalne naravi bilo bi paradoksalno bez slobode, koja je uvjet za njezino ostvarenje. Možemo zaključiti da je čovjek uistinu slobodan onda kada u djelovanju slijedi svoju urođenu racionalnu težnju za dobrim. Samo takvo djelovanje može s punim pravom nositi atribut slobodno. Napokon, sloboda u kojoj se odlučujemo za dobro jest sloboda u moralnom smislu. Ona znači slobodu od mogućnosti činjenja zla. Svakim, pa i najmanjim, svakidašnjim odabirom odlučujemo hoćemo li činiti dobro ili ne ćemo. Ako biramo dobro, djelujemo prema svojoj naravi, samoostvarujemo se. Ako se pak odlučimo za zlo, nijedna nas vanjska restrikcija ne će sapinjati tako čvrsto kao nesloboda našega duha. Za procjenu vlastitih čina treba tražiti pokretače naših djelovanja, odnosno motive ili dobra kojima volja teži. Ti pokretači povezani su s intencionalnošću ljudske naravi zahvaljujući kojoj smo otvoreni dobrima koja nam pomažu u ostvarivanju vlastite osobe. Podsjetimo da je naša razumska spoznaja intencionalna, to znači da um kada spoznaje uvijek spoznaje nešto. Isto tako i naša volja, koja je razumska težnja, teži uvijek nečemu, to jest teži nečemu pod vidikom dobra. Zato se slažemo s Tomom Akvinskim kada kaže da je intencionalnost vlastita volji. I ta intencionalnost ne odnosi se samo na konačni cilj kojemu teži volja nego i na sredstva koja su nam potrebna za

\footnotetext{
${ }^{37}$ Usp. R. LUCAS LUCAS, L'uomo lo spirito incarnato, 172.

${ }^{38}$ Usp. J. de FINANCE, Esistenza e libertà, 285.

${ }^{39}$ Usp. B. MONDIN, L'uomo libero, 201.
} 
postizanje toga cilja. ${ }^{40}$ Biranje tih dobara znači i dobre motive. Svaki čin učinjen u slobodi jest izričito moj i budući da je takav, usko je povezan s odgovornošću. Odgovornost je potvrda moje slobode. No oko pojma odgovornosti vladaju nedoumice. Tražimo opravdanja i zato se determinizam čini privlačan. Imajmo na umu da život u slobodi pretpostavlja par excellence ljudsku egzistenciju. Stoga kada je riječ o problemu zla, nužno je pogledati u nas, u ljude koji su njegovi arhitekti.

\subsection{GRANICE LJUDSKE SLOBODE}

Vidjeli smo da čovjek ima slobodu izbora, koja mu daje mogućnost samoostvarenja. No važno je reći da ta sloboda nije apsolutna, nego je u skladu s njegovom naravi. Često se u naše vrijeme može čuti da čovjek nije istinski slobodan ako postoji ograničenje njegova djelovanja, bez obzira na to odakle ono dolazilo. Po tom shvaćanju prava sloboda za čovjeka bila bi tek ona koja bi mu omogućila da čini ono što poželi, a često ju se naziva i apsolutna sloboda. Smatramo da je to pogrješno shvaćanje slobode. Naime, na taj način nije slobodan čak ni Apsolut. Možda se čini kontradiktorno, pa čak i skandalozno, takvom biću odricati apsolutnu slobodu. Međutim, i Apsolutno biće djeluje u skladu sa svojom naravi, a kako je po naravi nužno biće, onda ne može djelovati tako da ne bude. ${ }^{41}$ Čovjek je naime ljudski slobodan. Nije slobodan od svoje konstitucije, istovremeno je materija i duh, posrednik između dviju stvarnosti. Po tijelu je biće u vremenu i prostoru. Nije slobodan od činjenice da je spolno ili pak socijalno biće. Možemo mijenjati svoje tijelo, no ne možemo mijenjati svoju tjelesnost. Možemo mijenjati prostor u kojem se krećemo i živimo, no ne i činjenicu da ne možemo živjeti izvan prostora i vremena. Ne možemo se koristiti jezikom kako želimo, nego radi komunikacije. Na neki način ovisimo o svijetu, društvu i povijesti. Uvjetovani smo i moralnim vrijednostima koje se nameću našoj savjesti. ${ }^{42}$ Nadalje, čovjek nije slobodan od težnje za dobrim. ${ }^{43} \mathrm{Na}$ dobro nas obvezuje ljudska narav čiji biljeg nosimo - navedeno ne podliježe moći

\footnotetext{
${ }^{40}$ Usp. TOMA AKVINSKI, S. Th., I, q. 12. Izvrsnu analizu uzročnoga odnosa između ljudskoga intencionalnoga djelovanja i naravi ljudske osobe donosi nam S. Kos u svom članku »Metafizička narav osobe u pravnom poretku $\ll$ (usp. S. KOS, »Metafizička narav osobe u pravnom poretku «, u: M. STEINER (ur.), Ljepota istine. Zbornik u čast p. Miljenka Belića SJ u povodu 75. obljetnice života, Zagreb, 1996., 19.-33.). A veoma zanimljivu vezu između uživanja i intencionalnosti nalazimo objašnjenu u McInernyjevom djelu Aquinas on Human Action. Usp. R. McINERNY, Aquinas on Human Action, 62.-64.

${ }^{41}$ Recimo odmah da je naša mogućnost uspoređivanja ljudskoga i Božjega djelovanja vrlo ograničena te smo, prema Tomi Akvinskom, upućeni na analogni govor. Ovdje smo htjeli samo naglasiti da sloboda racionalnih stvorenih bića mora biti u skladu s njihovim naravi. Dakle, ako je biće ograničeno, tada je i njegova sloboda u granicama te naravi.

${ }^{42}$ Usp. A. ALESSI, Sui sentieri dell'uomo, 176.

${ }^{43}$ Usp. B. MONDIN, L'uomo libero, 216.-217.
} 
slobodnoga izbora. I o tome ne možemo odlučivati, riječ je o nečem što čovjek ne bira, nego mu je po naravi dano. Pitanje koje se usko veže uz ljudsku slobodu pitanje je njezinih granica. Na to dobro odgovara J. P. Sartre zaključivši da je granica moje slobode tvoja sloboda. To znači da ako se koristim vlastitom slobodom nauštrb drugog, riječ je o njezinu zloupotrebljavanju. Zapravo, takvo djelovanje uopće se ne može nazvati slobodnim. Činiti ono što me volja nije sloboda, nego nesloboda jer djelovanje ne slijedi iz razumskoga promišljanja, nego iz poriva. U takvom djelovanju volja je slijepa te je više nalik reakciji na poticaj. Problem nastaje kada se sloboda počinje zloupotrebljavati. Ako se ta predivna ljudska sposobnost ne koristi za dobro, čovjek zapada u zablude, postaje zao i okrutan.

\subsection{ZLOUPOTREBA SLOBODE I AKTUALNI PROBLEMI}

Kada čovjek ne djeluje u vidu samoizgrađivanja i na dobrobit zajednice, ciljevi postaju ništavni. Ako ne postoje jasno određene vrijednosti, ako kultura zapada u negiranje svega što nije opipljivo i mjerljivo, nastupa kriza i nesigurnost. Liberalno društvo koje sve dopušta samo je naizgled slobodno jer time što sve dopušta, ništa ne jamči. ${ }^{44}$ Više od materijalne krize pogađa kriza duha jer takva vodi do razaranja, ideologija i mržnje. Jedna je od tih i rodna ideologija, koja vuče korijene daleko iz prošlosti. ${ }^{45}$ Nemojmo se zavaravati da živimo u mirnim vremenima opravdavajući se mišlju da nema otvorenih sukoba u uređenoj i civiliziranoj Europi. Kriza vrijednosti naša je stvarnost. Činjenica je da se ne vidi, ne shvaća se kako je moguće poštovati, odobravati, cijeniti, voljeti, željeti. ${ }^{46}$ Čovjek je izgubio smjer s obzora, nema čvrste paradigme prema kojoj bi mogao vrjednovati svoje djelovanje. Svjesno popuštamo pred indoktrinacijama jer misliti vlastitom glavom predstavlja napor. $U$ našem potrošačkom društvu najprodavaniji su artikl ideje. Prije nego li se pitamo ima li takav život smisla, trebamo zaključiti da je on opasan. Što vrijedi sloboda onomu koji ne zna kamo ići ili kako djelovati? To je stanje plodno tlo za nicanje suvremenih ideologija. »Novi je totalitarizam fleksibilan i prilagodljiv vrijednostima koje su danas na cijeni, skriva se pod krinkom slobode dok istovremeno svakim korakom uništava preduvjet slobode. $\ll{ }^{47}$ Prema tumačenju Judith Butler rodna je ideologija anonimna. Zadire u ljudsku intimu, a ne znamo joj jasno ni ime ni podrijetlo. Pojam rod iz gramatičkih kategorija preselio se u političko i društveno područje te pretendira zamijeniti termin spol. Dok je spol biološka oznaka bića, rod

\footnotetext{
${ }^{44}$ Usp. R. LUCAS LUCAS, L'uomo lo spirito incarnato, 276.

${ }^{45}$ Kako navodi G. KUBY, pretečama rodne ideologije smatraju se pristaše francuske revolucije koji su se borili za liberté, égalité, fraternité.

${ }^{46}$ Usp. J. de FINANCE, Persona e valore, Roma, 2003., 261.

${ }^{47}$ G. KUBY, Svjetska seksualna revolucija, Zagreb, 2013., 438.
} 
je društvena te kao takva može biti izabrana. ${ }^{48}$ Ta ideologija djeluje pod krinkom postizanja prava žena. Više nije sigurno bore li se one za jednaka prava ili za istovjetnost s muškarcima. Kao glavni cilj zagovornici rodne ideologije postavljaju dekonstrukciju spolnoga identiteta. ${ }^{49}$ Taj cilj nije izabran nasumično. Pitanje spola područje je ljudske intime, čovjek je tu vrlo krhak i ranjiv te ponekad pitanje spolnosti postaje tabu-tema. Ako se uspije čovjeka ogoliti do njegove duboke intime, on postaje marioneta bez savjesti. Drugim riječima, čovjek postaje sredstvo. Ti se ideolozi deklariraju neumornim zagovarateljima slobode i ljudskih prava, a čovjeka pretvaraju u sredstvo. Nije li to eklatantan primjer proturječja? Ipak, rodna ideologija napreduje zahvaljujući prikrivenim idejama u marketingu, slatkorječivosti popularnih pjesama, promociji slobode na svakom planu. Cilj je srušiti obitelj kao stup društva, uništiti vrijednosti judeokršćanske tradicije. Ako mogu izabrati kojem ću spolu pripadati, koji je onda smisao braka? Obitelj postaje relativna i proizvoljna. Svakako, tu nema mjesta za djecu. I tome rodni ideolozi doskaču borbom za pravo žene na pobačaj. ${ }^{50}$ Žena može izabrati, kažu. Samo što ona želi birati o onome što nije predmet izbora. Nije sporno da zigota od trenutka začeća ima 46 kromosoma kao i svaki odrastao čovjek. No ta zigota ne sadržava genski materijal majke ni oca. Ona posjeduje svoj, jedinstveni genom. Također, nova se osoba razvija kontinuirano te je biološki jedinstvena. Sve se sastavnice razvijaju u savršenoj koordinaciji kao dijelovi jedne cjeline. ${ }^{51}$ Ti znanstveni podatci jednodušno upućuju na ispravno logičko-filozofsko zaključivanje da je zigota novi život, nova ljudska osoba. Zigota nema mogućnost postati ljudska osoba; ta je mogućnost aktualizirana u trenutku kada je nastala, dakle zigota jest ljudska osoba. Unatoč tim znanstvenim podatcima i filozofskim činjenicama, sve više država legalizira pobačaj. Čovjek ne satire više samo sebe nego i drugoga, čak i onoga najnemoćnijega. No rodni ideolozi ne prežu ni pred kakvim sredstvima, štoviše, proglašavaju ih dobrima. Pobačaj zato postaje mogućnost, i to lako ostvariva. ${ }^{52} \mathrm{Da}$ bi se postigao cilj rodnih ideologa, objavljuju se pseudoznanstveni radovi, provode se istraživanja da bi se na kraju ispostavilo da

${ }^{48}$ Tomu u prilog filozofkinja Judith Butler piše da je biološki spol idealna konstrukcija koju se s vremenom prisilno materijalizira (usp. G. KUBY, Nova ideologija seksualnosti, 51.).

${ }^{49}$ Kako objašnjava G. Kuby u svojoj knjizi Svjetska seksualna revolucija, dekonstrukcija spolnoga identiteta zapravo znači brisanje podjele ljudi na dva spola te uvođenje jednakovrijednosti i ravnopravnosti raznolikih spolova.

${ }^{50}$ Pobačaj ili abortus dolazi od latinske riječi aborior, koja znači 'umrijeti prije rođenja'. Jedan od glavnih argumenata za pobačaj jest pravo žene na vlastito tijelo. Međutim, od trenutka začeća embrij nije dio ženskoga tijela, nego je zasebno tijelo jedne nove osobe te taj argument prava na vlastito tijelo ne stoji.

${ }^{51}$ Usp. R. LUCAS LUCAS, Bioetika za svakoga, Split, 2007., 120.

${ }^{52}$ Diljem Amerike u klinikama za pobačaje abortus je moguće obaviti odmah za nekoliko stotina dolara (vidi D. KUPELIAN, Marketing zla, Split, 2010., 202.). 
su rezultati lažirani, sve je jača korupcija jezika, napada se, pa čak i zatvara svakoga tko se usudi misliti drukčije. Rezultat je svega toga manjinsko ugnjetavanje većine..$^{53}$ I ne, ovdje se ne dovodi u pitanje je li većina u pravu. Ta je većina tisućama godina živjela i živi u skladu s prirodom i društvom, gradeći tradiciju i običaje, ostavljajući golemo i vrijedno naslijeđe svojoj djeci. No još više svojim načinom života ta ih je tobožnja neprosvijećena i konzervativna većina odgajala za čestitost i pošten rad, sustezanje od hedonizma jer je neminovna njegova razornost. Problem je što je manjina vrlo glasna i diskreditira sve koji se protive. Možemo se pitati kakva je to sloboda mišljenja u društvu u kojem se smije čuti samo jedna strana, a sve je drugo diskriminacija, fobija i neprosvijećenost. ${ }^{54}$

Osoba može promijeniti mnogo toga - mjesto stanovanja, posao, način života, može čak mijenjati i stvarnosti, koristeći se jezikom. Primjerice, izricanjem vjenčanih zavjeta sklapa se brak. Ali neke su stvarnosti danosti i time su nepromjenjive. To znači da ne ovise o mojoj slobodnoj volji. Ma koliko god netko htio i nastojao, biologija se ne može promijeniti. Kao što se ne mogu promijeniti živci i kapilare koje tvore moje tijelo, ne mogu mijenjati ni spol po vlastitom nahođenju. Tim više što moj spol prožima moje tijelo i moj duh. Već smo rekli da čovjeku pripada sloboda po njegovoj naravi, pa je ona u skladu s njim ljudska. Trebamo si prestati laskati i pripisivati prava koja nam zapravo ne pripadaju. $U$ prava koja nam ne pripadaju ubraja se i pobačaj. Ljudska je osoba vrijedna i neponovljiva, a i jednom nastala, moguće je da nikad ne nestane. Kad bismo u potpunosti bili svjesni značenja toga iskaza, shvatili bismo i jedinstveni status ljudskih bića. Možemo se opravdavati raznim ideologijama, pravima i slobodama, ali zločin ostavlja mrlje na savjesti i ne dopušta mir, kako nam svjedoče mnogi koji su činili pobačaje. ${ }^{55}$ Čini nam se da nam sloboda nije ugrožena, no pred našim očima ugrožava se sloboda u ime slobode. ${ }^{56}$ Danas se govori da treba izbrisati društvene nejednakosti i s time se slažemo. No ako se pod tim smatra izbrisati podjelu na spolove, onda je društvo došlo do teške devijacije. Prirodni spol nije nejednakost, nego raznolikost. Trebamo presta-

${ }^{53}$ D. KUPELIAN navodi knjigu Marshalla Kirka i Huntera Madsena After the Ball: How America Will Conquer Its Fear and Hatred of Gay in the '90 (Poslije Bala: kako će Amerika pobijediti svoj strah $i$ mržnju prema homoseksualcima u '90-ima), New York, Penguin, 1989. U njoj autori, marketinški stručnjaci s Harvarda, jasno iznose način na koji će se obistiniti sadržaj naslova knjige (vidi D. KUPELIAN, Marketing zla, 21.).

${ }^{54}$ G. KUBY donosi podatke o ugnjetavanju katolika: španjolska vlada kaznila je katolički TV-kanal sa 100000 eura jer su prikazivali reklamnu seriju za obitelj, a protiv homoseksualnoga načina života. Taj i brojne druge primjere autorica navodi u svojoj knjizi Svjetska seksualna revolucija, 416.-418.

${ }^{55}$ Kao primjer navodimo potresnu ispovijest Davida Brewera i Anthonyja Levantina (vidi D. KUPELIAN, Marketing zla, poglavlje 9.).

${ }^{56}$ Usp. G. KUBY, Nova ideologija sekusalnosti, Split, 2010., 84. 
ti pokušavati nadmudriti prirodne zakone, oni nisu domena ljudskoga djelovanja. Naprotiv, naša zadaća nije složena, mi trebamo živjeti u skladu s njima. Imamo li uopće u vidu fizičke, psihičke, pa čak i duhovne anomalije koje bi mogle proizići iz neprirodnoga načina života? Svaki je čovjek u svojoj tjelesnoj konstituciji, želio on to ili ne, spolno biće, a ta vlastitost određuje cijeli njegov bitak. ${ }^{57}$ Svaka je osoba pripadnik jednoga od dvaju spolova i kao takva nosi nepromjenjivu biološku narav koja određuje u određenoj mjeri njezin život. Pripadnost određenom spolu naša je stvarnost te je ne možemo mijenjati koristeći moć slobodnoga izbora. Činjenica da se čovjek rađa kao muškarac ili žena nije indiferentna za individualno biće. Ta činjenica u sebi nosi način bivstvovanja koji vrlo brzo usmjerava tijek svijesti u zadanim pravcima jer se treba izgraditi za budućnost. ${ }^{58}$ Ovdje nema mjesta relativiz$\mathrm{mu}$, ovdje je riječ o neupitnoj i nedokidivoj vlastitosti ljudske naravi. To nije ni teza ni teorija, tu činjenicu potvrđuje i biologija. ${ }^{59} \mathrm{Osim}$ jasnih anatomskih, fizioloških i hormonalnih razlika koje ocrtavaju spol, itekakve razlike nalazimo i na psihičkoj razini. Oba spola dijele istu ljudsku narav, no ona se aktualizira na dva različita načina. Zbog svih tih problema vidimo da je »sve veća potreba u suvremenom svijetu da, osim 'ljudskih' prava, trebamo razmatrati i štititi prava svake pojedine ljudske osobe. A da bismo ih mogli stvarno zaštititi moramo ih poznavati, jer je nemoguće govoriti o pravima ili obvezama ljudske osobe, a da ne znamo što je osoba $\ll^{60}$. U posljednjem poglavlju postavljamo si za zadaću pokazati koji je uistinu najveći izraz ljudske slobode, gdje se ona najjasnije očituje i koja je krajnja svrha te čovjekove nepobitne vlastitosti.

\section{Ljubav i sloboda kao nosivi stupovi osobnoga života}

Sloboda ako se krivo poima postaje razorna te se gubi njezin posljednji i uzvišeni smisao: sposobnost ljubljenja. Ako se pojmom slobode opravdava pripisivanje prava koja nam ne pripadaju, ona gubi smisao, ukida samu sebe jer nije shvaćena u uzajamnu zajedništvu s drugim slobodnim osobama. ${ }^{11}$ A upravo taj dodir moje slobode sa slobodama drugih osoba daje mi mogućnost upoznavanja drugih koji su različiti od mene, stvaranja odnosa s njima te naposljetku daje mi mogućnost da ih ljubim. Budući da voljeti mogu samo osobe, potrebno je reći nešto o vrijednosti osobe.

\footnotetext{
${ }^{57}$ Usp. R. LUCAS LUCAS, L'uomo lo spirito incarnato, 203.

${ }^{58}$ Usp. C. FABRO, Problemi dell'esistenzialismo, u: R. Lucas Lucas, L'uomo lo spirito incarnato, 204.

${ }^{59}$ Muški spol genetski je označen dvama različitim kromosomima $x y$, dok je ženski spol označen dvama istim kromosoma $x x$. Ta danost ne može se promijeniti umjetnim, pravnim, estetskim ili kirurškim pothvatima.

${ }^{60}$ Usp., B. DADIĆ, Filozofija i zbilja, 117.

${ }^{61}$ Usp. J. RATZINGER, Vjera - istina - tolerancija, Zagreb, 2004., 223.
} 


\subsection{NeOtuĐiVA VRIJEDNOST OSOBE}

Ranije smo pokazali kako čovjek djeluje motiviran vrijednostima koje prepoznaje u stvarima oko sebe te ih rangira kao više i manje vrijedne, pa čak i bezvrijedne. Vrijednosti ne zaobilaze ni čovjeka. Čovjek jest vrijednost, nosi neotuđivu vrijednost osobe. Poneki se autori često u našem vremenu pojmovima čovjek i osoba koriste kao sinonimima što može dovesti do izvjesne nejasnoće. U tom smislu dobro je imati na umu da to ipak nisu istoznačnice. Premda se oba pojma odnose na ljudsko biće, ipak, pojam čovjek odnosi se više na biološko-socijalno poimanje te u tom smislu odgovara pojmu individua, dok je pojam osoba rezerviran za filozofsku definiciju ljudskoga bića, promatrano u njegovoj cjelovitosti. Neki su suvremeni personalisti, poput $\mathrm{N}$. Berdjajeva i J. Maritaina, bili jako svjesni te distinkcije. ${ }^{62} \mathrm{Za} \mathrm{N}$. Berdjajeva osoba je ponajprije duhovna kategorija, ona je neovisnost u odnosu na materijalni svijet. ${ }^{63} \mathrm{To}$ je vidljivo u samoj metafizičkoj konstituciji čovjeka, stoga zaključujemo da čovjeku pripada pojam osoba po njegovoj metafizičkoj naravi. Toma Akvinski donosi svoju definiciju: »osoba je sve ono što subzistira u umskoj ili razumskoj naravi. ${ }^{64}$ On je svoju definiciju izgradio na tragu prve filozofske definicije koju je donio S. Boetije, a koja kaže da je osoba $\gg$ pojedinačna supstancija razumske naravi $\ll^{65}$. Možemo vidjeti da se pojam osobe vrlo rano počeo razvijati, a njegova svevremenska aktualnost pokazuje da nije riječ o nekom prolaznom trendu. Savršenost osobe ne temelji se na njezinu djelovanju u svijetu, nego na onome što je ona u sebi. ${ }^{66}$ Jedinstvenost je osobina koja jamči personalizirani egzistencijalni smisao koji dolazi po životnom pozivu. Međusobno se razlikujemo po tijelu, no i po duši. Pa kad bi se i kloniralo ljudsko tijelo, osobu se nikad ne će moći klonirati. Neotuđivost je usko vezana za jedinstvenost ljudske osobe. To ne znači ništa drugo nego da je čovjek pounutrašnjeno biće. Tako će moje misli uvijek biti samo moje i nitko ne može imati izravan uvid u njih. To je nedodirljiv trenutak ljudske naravi. Navedene dvije osobine slijedi pojedinačnost, po kojoj je osoba cjelina za sebe, a ne mali dio neke veće cjeline. Osobna su prava iznad općih prava. ${ }^{67}$ Dalje, cjelovitost znači potpunost osobe u njezinoj konstituciji,

${ }^{62}$ Usp. N. BERDJAJEV, Ja i svijet objekata, Zagreb, 1984., 121.-152. i J. MARITAIN, Tri reformatora, Split, 20.-34.

${ }^{63}$ Usp. N. BERDJAJEV, O čovekovom ropstvu i slobodi, Novi Sad, 1991., 51.

${ }^{64}$ Usp. T. AKVINSKI, CG IV, c. 35: »omne subsistens in naturae rationali vel intellectuali est persona.«

${ }^{65}$ S. BOETIJE, Contra Eutychen et Nestorium, III, 1-6: PL, 64, 1343: »individua substantia rationalis naturae $\ll$.

${ }^{66}$ Usp. B. DADIĆ, I. KNEŽIĆ, Metafizička istraživanja o osobi, u: Riječki teološki časopis 17(2009.)2, 543.-572., ovdje 554.

${ }^{67}$ Razlikujemo pojedinačna i osobna prava. Dok nam prva pripadaju kao individualnim bićima i podložna su općim pravima koje donosi država, društvo i dr., osobna prava pripadaju isključivo osobi i ta nadilaze opća. Riječ je o pravu na slobodu, istinu itd. (usp. B. DADIĆ, Odnos pojedinačnog i općeg dobra u perspektivi metafizike osobe, u: Filozofska istraživanja 92(2004)1, 41.-58.). 
u supstancijalnom jedinstvu duše i tijela. Zato je potrebno na nju gledati pod vidom sveobuhvatnosti jer joj svaka primjesa redukcionizma odriče neku od osobina i na taj način svodi je na sredstvo. Iako je osoba svijet u sebi, nije samo za sebe. Time smo došli do relacionalnosti, osobine koja nas konstitucijski okreće prema drugo$\mathrm{mu}$, jednakom po vrijednosti koju smo spoznali u sebi. Ovdje nije riječ o usputnom zaključku, nego o bitnoj osobini ljudske naravi. Bit ljudske naravi jest biti za drugoga. Autonomija kao posljednja osobina znači gospodarenje sobom i svojim djelovanjem te preuzimanje odgovornosti za vlastite odluke. Osoba je autonomni subjekt bivstvovanja i djelovanja upravo zbog racionalne naravi. ${ }^{68}$ Prethodno spomenuti problemi naše svakidašnjice ukazuju na sustavno zanemarivanje navedenih osobina te tako priječe put svrsi ljudskoga bivstvovanja.

\subsection{Samoostvarenje}

Dosad smo vidjeli neosporive osobine i mnogobrojne mogućnosti ljudske osobe. Njezine sposobnosti graniče s onostranim. Ali sve je to dano kao dužnost, na korištenje za dobro. Osoba je subjekt neotuđivoga prava po svojoj naravi, no ona ga mora takvim i pokazivati, mora biti odraz te intrinzične vrijednosti. ${ }^{69}$ Vrijednost osobe po svojoj je biti nedokidiva, no ona i usmjerava ljudski život u smjeru koji ne poznaje nijedno drugo biće. Tijelo raste bez našega posebnoga zalaganja, krećemo se i hranimo iz fizioloških potreba, no ovo drugo zahtijeva naš napor i htijenje. Duhovnost ljudske osobe nadilazi prirodne urođene poticaje, štoviše, nalaže da ih se pretvori u sluge, a ne da gospodare osobom. Što znači dakle da čovjek nije osuđen na egzistenciju okovanu instinktivnim djelovanjem? To su nastojanja da se vlastita osoba izdigne iz determiniranoga svijeta reakcija i usmjerenosti na vlastito ja. To nije nikakvo pretjerano bavljenje sobom, već je riječ o temeljnoj ljudskoj zadaći, a naziva se samoostvarenje. Svaka moja odluka, svaki čin oblikuje moj karakter upravo zato što dolaze od mene. Isto kao što moram nadići afektivna stanja i naučiti se promišljenom djelovanju, a ne ostati u slijepu reagiranju, dužna sam i ostvariti sve one mogućnosti koje pronalazim u sebi kao sklonosti. Zadaća mi je dakle ozbiljiti potencije koje imam. Zato se samoostvarenje još naziva i samoaktualizacija. ${ }^{70}$ I na taj način otkriva se smisao vlastitoga života, osobne causae finalis. Ne čekajući, nego djelujući, spoznajući se. Čovjek je po svojoj naravi i stvaralac, ne samo potrošač. No uvjet je moralnost jer samo takvo djelovanje ima moć aktualizacije. Ipak, samoostvarenje je obilježeno trajanjem; potreban je cijeli život za isto. Ali tek kada

\footnotetext{
${ }^{68}$ Usp. K. WOJTYŁA, I fondamenti dell'ordine etico, Città del Vaticano, 1980., 139.

${ }^{69}$ Osoba je nositelj prava zasnovana na osobnom dostojanstvu koje, kao što smo vidjeli, utemeljuje njezin vlastiti actus essendi. Pod određenim vidikom može se reći da je ona istovremeno i nositelj i objekt prava.

${ }^{70}$ To ne znači međutim da je samoostvarenje moguće izvan granica moje ljudske naravi.
} 
biti za sebe postane biti za drugoga riječ je o istinskom samoostvarenju. ${ }^{71}$ Ono se nalazi u samonadilaženju i samozaboravu, u ljubavi. Ljubav koju obrazlažemo traži ponajprije zahtjevnost prema sebi. Bitno je stoga objasniti kakva je ta ljubav da se ne bismo zavaravali i zatvarali u slatkorječivost raznih vrsta ili, još gore, u sve ono što neopravdano nosi ime ljubavi.

\subsection{Autentično ostvarenje osobe u uZajamnoj Ljubavi}

Nemoguće je previdjeti tolike pokušaje opisa stvarnosti ljubavi, o njoj govore i znanstvene discipline, dakle i filozofija. Najšira razdioba ljubavi u filozofskom smislu jest na naravnu, osjetilnu i racionalnu. ${ }^{72} \mathrm{U}$ kontekstu naravne ljubavi riječ je o težnji prema dobru kojem biće teži po svojoj naravi, dok je osjetilna ljubav ${ }^{73}$ težnja prema dobru koje je subjekt spoznao kao dobro za sebe, no bez intervencije razuma pa je to dobro shvaćeno kao nužnost koja je potrebna ovdje i sada. Razumska ljubav jest ona koju stavljamo u središte interesa. Kako joj samo ime kaže, pretpostavlja sud i slobodnu odluku volje. No i ta vrsta ljubavi dijeli se na još dvije: požudnu ljubav ili amor concupiscentiae te dobrohotnu ljubav ili amor benevolentiae. ${ }^{74} \mathrm{U}$ požudnoj ljubavi nije riječ o osjećanju nekoga nedostatka, nego je ta ljubav žudnja za osobom. ${ }^{75}$ Ona okuplja emocije, zadovoljstva, požude, strasti. U požudnoj se ljubavi dakle kristalizira objektivna potreba bića usmjerena prema drugome biću. Nije žudnja, nego želja za vlastitim dobrom. ${ }^{76}$ Ako ta ljubav nije podložna onoj uzvišeni-

${ }^{71}$ Usp. B. DADIĆ, I. KNEŽIĆ, Metafizička istraživanja o osobi, 566.

${ }^{72}$ Usp. B. MONDIN, Dizionario enciclopedico del pensiero di S. Tommaso D'Aquino, http://www.ecodellarossa.it/ditutto/biblioteca/Dizionario-enciclopedico-del-pensiero-di-S-Tommaso-DAquino. $\operatorname{pdf}$ (13. VIII. 2014.). Napominjemo da smo ovdje slijedili tomističku podjelu vrsta ljubavi, premda svjesni da se ljubav još u antičkoj misli dijeli na tri: eros, agape i phila (usp. »Love «, u: https://plato. stanford.edu/entries/love/ (13. VIII. 2014.). Postoji podjela i na četiri vrste, na primjer kod C. S. Lewisa: storge - privrženost, philia - prijateljstvo, eros - zaljubljenost i agape - karitas ili milosrdna ljubav (usp. C. S. LEWIS, Četiri ljubavi, Split, 2012.).

${ }^{73}$ Tu vrstu ljubavi Toma Akvinski naziva osjetilnom. Usp. B. MONDIN, Dizionario enciclopedico del pensierodi S.Tommaso D’Aquino, 4.-5.

${ }^{74}$ Ovdje ćemo dijelom slijediti K. Wojtyłu u njegovu djelu Ljubav i odgovornost, gdje on na metafizičkoj analizi ljubavi dograđuje psihološku ili, kako on precizira, »psiho-fiziološku, odnosno bio-psihološku analizu « (usp. K. WOJTYŁA, Ljubav i odgovornost, Split, 2009., 68.). Također treba imati na umu da se u Wojtyłinoj analizi ljubav promatra i kao krjepost. Naravno, ostaje mogućnost da se i podjele kojima se Wojtyła koristi mogu shvatiti više kao dimenzije ili sastavnice ljubavi nego kao vrste ljubavi. U svakom slučaju za njega sama riječ ljubav posjeduje izrazito analogan smisao (usp. isto, 67.).

${ }^{75}$ Usp. K. WOJTYŁA, Ljubav i odgovornost, Split, 2009., 76. K. Wojtyła ovdje jasno razlikuje ljubav požude od same požude.

${ }^{76}$ Usp. isto, 76. 
joj vrsti ljubavi, postoji opasnost da se pretvori u razaranje osobe. Amor benevolentiae ili dobrohotna ljubav upravo je ona koju smatramo istinskom ljubavi. Njezina je bit u samozaboravu. Požudnom ljubavlju volimo drugoga jer nam donosi dobro. Sasvim je suprotna dobrohotna ljubav, njome ljubimo radi dobra voljene osobe. Njezin je zahtjev vrlo jednostavan: zaborav na vlastitu osobu i promicanje voljene osobe. No takvom ljubavlju treba znati voljeti, zato ona ne može biti osjećaj. Ako je požudna ljubav utkana u dobrohotnu, a taj slučaj nalazimo u bračnoj ljubavi, onda nema opasnosti od iskorištavanja jer je kontrolira upravo ona ljubav koja prije svega vidi drugoga u njegovim potrebama. Ipak, u tako jednostavnom zahtjevu sadržano je mnogo toga. Prije svega to su tri ključna elementa koja definiraju tu vrstu ljubavi. Na prvom mjestu to je volja. Mi svojom slobodnom voljom odlučujemo voljeti osobu koju smo spoznali. I ta je odluka, jednom donesena, neopoziva. Potom slijedi objektivno dobro koje izbliza slijedi volju. No točno određeno dobro, a to je dobro za voljenu osobu. Dakle, sva moja djelovanja usmjerena su promicanju dobra onoga kojega volim, bez interesa i ikakve primjese vlastite koristi. Svojim snagama nastojim dostići savršenost voljene osobe, njezino samoostvarenje. U tom nastojanju čak i zaboravljam samoga sebe, zato se ta ljubav naziva i samozaboravnom. I u konačnici onaj tko konstituira dobrohotnu ljubav jest sama osoba. Ljubljena osoba viđena je kao drugo ja jer istinske odnose s drugim ljudima mogu ostvariti tek kada svakoj pojedinoj osobi priznam istu vrijednost i dostojanstvo koje priznajem i sebi kao osobi. ${ }^{77}$ Budući da sam spoznala onu neotuđivu vrijednost i savršenu neponovljivost osobe, ja je ljubim. Polako smo definirali najviši ljudski čin, pronašavši ga u autentičnoj ljubavi. Ljubav je naime vrhovna aktualizacija ljudskih potencija jer u sebi uključuje cjelovitu ljudsku osobu sa svim njezinim sposobnostima. No autentična ljubav može biti samo uzvraćena ljubav. Nepodijeljena ljubav ne može činiti zajedništvo, ne može biti ljubav samo s jedne strane. ${ }^{78}$ Nije ljubav ako dolazi iz krivih pobuda. U prethodnom smo poglavlju vidjeli da moramo voditi računa o motivima i ciljevima kojima se usmjeravamo. Autentična ljubav međutim traži postajanje boljim radi voljene osobe, ne zbog ljubavi. Već smo naznačili da moju nutrinu nitko ne može pregledati. Upravo zbog toga je ona naša vrijednost: ne može je spoznati nitko doli voljena osoba kojoj je poklonimo. To pak znači da se ljubav temelji i na vjeri. Najdublji je smisao osobe, kaže Solovjev, priznavanje bezuvjetnoga značenja voljene osobe. ${ }^{79}$ Povrh toga, prava ljubav, ona koja je usmjerena na drugoga, moguća je samo preko ljubavi prema Vrijednosti..$^{80}$ To je glavna referenca autentične ljubavi, Vrijednost je temelj na kojoj počiva njezina istinitost. Samo je

\footnotetext{
${ }^{77}$ Usp. B. DADIĆ, I. KNEŽIĆ, Metafizička istraživanja o osobi, 563.

${ }^{78}$ N. BERDJAJEV, Ja i svijet objekata, 85., 125.-126.

${ }^{79}$ Usp. V. SOLOVJEV, Smisao ljubavi, Split, 2011., 66.

${ }^{80}$ Usp. J. de FINANCE, Saggio sull'agire umano, 177.
} 
zato takva ljubav i moguća, jer je moralna. Odlučiti voljeti na taj način zasigurno je zahtjevno. Uvijek postoji mogućnost neuspjeha i patnje, no na neki način svako naše djelovanje može rezultirati promašajem. Ipak, svaki put odlučimo djelovati jer je to, uostalom, i dio naše naravi. Mogli bismo zaključiti da je autentična ljubav vrijedna toga rizika. Na kraju, kakav bi bio ljudski život bez ljubavi? Svrha ljudskoga života, sada se usuđujemo reći, jest ljubav. Autentična ljubav ostvaruje se u svakom istinskom prijateljstvu i bračnoj ljubavi koja se širi na obiteljsku, odnosno ljubavi roditelja prema djeci. Takve ljubavi temeljene su na zajedničkoj svrsi kojoj se upućuju osobe u ljubavi jer su je izabrale. Sloboda je dakle ključan trenutak ljudske egzistencije. Istina je da se u svakome od nas nalazi nešto što kod voljene osobe zahtijeva praštanje, trpljenje, podnošljivost. ${ }^{81}$ Zato je amor benevolentiae nazvana još agape, a označava milosrdnu ljubav. U najužem smislu samo je ta ljubav istinska jer je potpuno čista i slobodna, ništa je ne sapinje, može čak voljeti i ono što se naizgled čini nemoguće! Samo ćemo na taj način biti sigurni da smo učinili sve što je u našoj moći da možemo ljubiti vječnom ljubavlju, koju samo predosjećamo u nesavršenosti propadljivoga svijeta.

\section{Zaključak}

Poticaj za pisanje ovoga članka bila je sve veća potreba za odgovarajućim objašnjenjem ljudske osobe, zbog čijega krivoga i nepotpunoga shvaćanja dolazi do pogubnih posljedica. Zato smo problematici pristupili sveobuhvatno, ne ispuštajući iz vida nijedan od aspekata ljudske naravi. Shvatili smo da je materija u čovjekovu slučaju produhovljena. Ta nepobitna činjenica nije svrha samoj sebi, nego je u djelovanju dviju bitnih ljudskih moći zahvaljujući kojima je čovjek refleksivno i slobodno biće. Povrh toga, čovjek je biće koje teži prema razumski spoznatom dobru. Ta je težnja dakle razumska, no za nju se odlučuje po slobodnom odabiru, a čin njegove volje uvijek je samo njegov. Budući da čovjek već po naravi teži prema dobru, on je uistinu slobodan samo onda kada izabere dobro. Ipak, događa se da se moćima koje imamo koristimo u krive svrhe pa sloboda postaje čovjekova vlastitost koju najviše zlorabimo. Zato smo došli do stanja u kojem se moramo štititi sami od sebe. Dajemo si za pravo čak i ubiti drugu osobu, inzistiramo na promjeni nepromjenjivih stvarnosti poput prirodno određenoga spola. $S$ druge strane, sloboda je dana radi ljubavi, a voljeti mogu samo osobe. Osoba koja je nepovrediva vrijednost u sebi može se samoostvariti jedino izabravši benevolentnu ljubav.

${ }^{81}$ Usp. C. S. LEWIS, Četiri ljubavi, 164. 


\section{MAN AND HIS FREEDOM}

\section{Borislav DADIĆ - Cecilija NEKIĆ*}

Summary: The paper deals with freedom as man's particular perfection. We start from the metaphysical constitution of a person in order to clearly show why man is a free being. It concerns man as a substantial unity of form and matter, and reason and will, the two powers inherent exclusively to man. We bring certain philosophical reflections on human freedom and a critical judgement of current social phenomena such as gender ideology and abortion, as clear examples of unacceptable understanding of human freedom. Because of many problems related to the contemporary understanding of man, we want to draw attention to the inalienable value of the person, as well as to the highest act in which freedom is manifested. It is a person's capacity for self-realization in authentic love.

Keywords: metaphysical constitution, freedom, person, gender ideology, abortion, self-realization, love.

\footnotetext{
* Assoc. Prof. Borislav Dadić, Ph. D., Department of Philosophy, University of Zadar, Obala kralja Petra Krešimira IV. 2, 23000 Zadar, Croatia, bdadic@unizd.hr

Cecilija Nekić, mag. educ. phil., mag. philol. ital., Seventh Grammar School, Križanićeva 4, 10000 Zagreb, Croatia, cecilija.nekic@gmail.com
} 